\title{
Onion production costs as a function of water content and soil tillage
}

\author{
Jardênia R. Feitosa ${ }^{1}$, Haroldo C. Fernandes², Paulo R. Cecon², Mauri M. Teixeira², Anderson G. Costa ${ }^{3}$ \& \\ Edival C. da Silva ${ }^{4}$ \\ ${ }^{1}$ Universidade Federal do Vale do São Francisco, Juazeiro, BA, Brasil. E-mail: jardenia.rodrigues@univasf.edu.br (Corresponding author) - ORCID: \\ 0000-0001-6019-4941 \\ ${ }^{2}$ Universidade Federal de Viçosa, Viçosa, MG, Brasil. E-mail: haroldo@ufv.br - ORCID: 0000-0001 5276-5441; cecon@ufv.br - ORCID: 0000-0001-8213- \\ 0199; E-mail: mauri@ufv.br - ORCID: 0000-0003-2051-2161 \\ ${ }^{3}$ Universidade Federal Rural do Rio de Janeiro, Seropédica, RJ, Brasil. E-mail: acosta@ufrrj.br - ORCID: 0000-0003-0594-8514 \\ ${ }^{4}$ Universidade Federal de Campina Grande, Campina Grande, PB, Brasil. E-mail: eng.edival@gmail.com - ORCID: 0000-0003-0708-0173
}

\begin{abstract}
Onion production is an agricultural activity whose yield is associated with environmental, market and cultural management factors. The objective of this study was to evaluate the cost of onion production as a function of the tillage system adopted and the soil water content at the moment of the operations. Three tillage systems were evaluated: P1 - one plowing + two harrowings + two seedbed raising operations; P2 - two harrowings + one seedbed raising operation; P3 - one harrowing + one seedbed raising operation; and four soil water contents: $12,15,23$ and $26 \%$, in experiment conducted at the Tourão irrigated perimeter, Juazeiro, BA, Brazil ( $9^{\circ} 24^{\prime} 07.3^{\prime \prime}$ S; $40^{\circ} 26^{\prime} 08.7^{\prime \prime} \mathrm{W}$, and altitude of $376 \mathrm{~m}$ ), in 2017, in split plots, in a randomized block design, with four repetitions. The costs related to mechanized operations, manual operations, inputs and crop irrigation were determined. The economic efficiency was evaluated through the variables total cost and unit cost of onion production, gross revenue, net revenue and internal rate of return. The use of the tillage system with one harrowing, one seedbed raising operation and seeding, under the condition of $23 \%$ soil water content, resulted in higher economic efficiency.
\end{abstract}

Key words: Allium cepa, economic efficiency, agricultural mechanization

\section{Custos de produção de cebola em função do teor de água e preparo do solo}

RESUMO: A produção de cebola é uma atividade agrícola cujo rendimento está associado a fatores ambientais, de mercado e ao manejo cultural. Objetivou-se com este estudo avaliar o custo de produção de cebola em função do sistema de preparo adotado e do teor de água do solo no momento de realização das operações. Foram avaliados três sistemas de preparo: P1 - uma aração + duas gradagens + duas operações de encanteiramento; P2 - duas gradagens + uma operação de encanteiramento; P3 - uma gradagem + uma operação de encanteiramento; e quatro teores iniciais de água do solo: 12, 15, 23 e 26\%, em experimento conduzido no perímetro irrigado Tourão, Juazeiro, BA ( $9^{\circ} 24^{\prime} 07.3^{\prime \prime} \mathrm{S} ; 40^{\circ} 26^{\prime} 08.7^{\prime}$ ' W, e altitude de $376 \mathrm{~m}$ ), em 2017, em parcelas subdivididas, no delineamento em blocos casualizados, com quatro repetições. Foram determinados os custos referentes às operações mecanizadas, operações manuais, insumos e a irrigação da cultura. A eficiência econômica foi avaliada por meio das variáveis custo total e custo unitário de produção da cebola, receita bruta, receita líquida e taxa interna de retorno. A utilização do sistema de preparo com uma gradagem, um encanteiramento e semeadura, na condição de teor de água do solo a 23\%, resultou em maior eficiência econômica.

Palavras-chave: Allium cepa, eficiência econômica, mecanização agrícola 


\section{INTRODUCTION}

Determining production costs in agriculture is a key factor for decision-making regarding the profitability of the agricultural activity (Oliveira et al., 2011; Costa et al., 2015; Corso et al., 2018; Feitosa et al., 2018). In the cultivation of onions (Allium cepa L.), controlling the costs becomes essential as it is an expensive, high-risk activity, due to the great variation in marketing prices (Barakade et al., 2011; Silva et al., 2014).

The production of this vegetable is strongly influenced by environmental factors and agronomic practices adopted, which include the different soil tillage systems (Menezes Júnior \& Kurtz, 2016; Moraes et al., 2016; Loss et al., 2017). In the conventional tillage system, onion cultivation is characterized by excessive soil turning, and plowing and clod-breaking operations are performed (Loss et al., 2015).

Soil tillage is the most expensive agricultural operation (Özgöz et al., 2017), and therefore, carrying out excess operations tends to increase the total cost of production, reducing crop profitability. In the Sub-middle São Francisco Valley, the "ideal" soil tillage for onion cultivation is usually defined by the producers empirically, which leads to higher cost.

For Heidarisoltanabadi \& Tahani (2016), the energy demand and the cost of onion production are quite high and, therefore, their determination can provide new perspective so that ways to reduce them are implemented.

Thus, the objective of this study was to evaluate the cost of onion production according to the tillage system and soil water content at the moment of the operations, under the conditions of the Sub-middle São Francisco Valley.

\section{Material ANd Methods}

The study was conducted in an area located in the Tourão irrigated perimeter, in the municipality of Juazeiro, Bahia, Brazil (9॰ $24^{\prime} 07.3^{\prime \prime}$ S; $40^{\circ} 26^{\prime} 08.7^{\prime \prime}$ W, and altitude of $376 \mathrm{~m}$ ) from June to October 2017.

An experiment was installed in split-plot scheme, with four initial soil water contents in the plots and three soil tillage systems in the subplots, in a randomized block design, with four replicates. Each experimental unit corresponded to one seedbed with a width of $1.25 \mathrm{~m}$ and length of $20 \mathrm{~m}$.

The volumetric soil water contents evaluated $(12,15,23$ and $26 \%$ ) were obtained by applying water depths on the soil surface, before the operations were carried out, using a microsprinkler system. The wetting process was monitored with an electronic moisture meter HidroFarm, model HFM2130.

The soil tillage systems evaluated were composed of one plowing, two harrowings and two seedbed raising operations
(P1); two harrowings and one seedbed raising operation (P2); and one harrowing and one seedbed raising operation (P3).

For soil tillage, the following machines/implements were used: a 4 × 2 tractor, Valtra brand, BM 110 model, with auxiliary front-wheel drive (AFWD) and power of $116 \mathrm{hp}(85$ $\mathrm{kW}$ ) at engine rotation of $2300 \mathrm{rpm}$; a one-way plow, Tatu Marchesan brand, AF model, with three discs of 26 " $\times 4.75 \mathrm{~mm}$ and theoretical cutting width of $0.92 \mathrm{~m}$; an off-set harrow, KLR brand, GAC245 1424 model, with 14 discs of 24" spaced by $0.254 \mathrm{~m}$ and theoretical working width of $1.75 \mathrm{~m}$; and a rotary hoe equipped with seedbed raiser, Mec-Rul' brand, ERP 150 model, with theoretical cutting width of $1.50 \mathrm{~m}$ and seedbed width of $1.25 \mathrm{~m}$, working with the impact plate fully lowered.

Crop planting was carried out using a pneumatic, precision seeder, Jumil" brand, Natura Air 2400 model, five planting rows and usable width of $1.64 \mathrm{~m}$. Its pneumatic meter was equipped with smooth vertical discs, which had 120 holes with diameter of $0.01 \mathrm{~m}$, for onion sowing in double row. The seeder was regulated to deposit 20 seeds per linear meter, at a depth of $0.012 \mathrm{~m}$, with spacing of $0.10 \mathrm{~m}$ between single rows and of $0.15 \mathrm{~m}$ between double rows.

The cost of onion production was determined by surveying the expenses involved in the process, from soil tillage to product packaging. These expenses were subdivided into: costs with mechanized operations, costs with manual operations, costs of irrigation system and cost of the inputs used.

The cost of the use of agricultural machinery, composed of depreciation, interest, shelter and insurance, repairs and maintenance, fuel, lubricants and labor, was calculated for each mechanized set considering the variation of use caused by the treatments.

The estimated useful life in years, the useful life in hours and the residual value of the machines were obtained from the data made available by CONAB (2010) and are presented in Table 1, together with the acquisition values of each machine.

Depreciation, described as the change in the value of agricultural machinery due to age, use or obsolescence, was determined by the linear method (ASABE, 2011a). The cost of interest was calculated as a percentage of the average investment made in each machine according to Painter (2011), considering the annual interest rate applied to the Moderfrota Program for the agricultural year 2017/2018, which was 7.5\%.

The portions referring to shelters and insurance were calculated according to ASABE (2011a), which recommends that they be estimated as percentages of the purchase price of the machines, using the values of $0.75 \% \mathrm{p}$. a. for shelters and $0.25 \%$ p. a. for insurance.

The cost with repairs and maintenance was estimated through the equation provided by ASABE (2011a), which estimates the total costs of all spare parts, materials and labor

Table 1. Values of acquisition, useful life and residual value of the machines used

\begin{tabular}{lccccr}
\hline Machines & $\begin{array}{c}\text { Acquisition } \\
\text { value (R\$) }\end{array}$ & $\begin{array}{c}\text { Date } \\
\text { of acquisition }\end{array}$ & $\begin{array}{c}\text { Useful life } \\
\text { (years) }\end{array}$ & $\begin{array}{c}\text { Useful life } \\
\text { (h) }\end{array}$ & $\begin{array}{c}\text { Residual value } \\
\text { (\%) }\end{array}$ \\
Valtra tractor & $154,980.00$ & $09 / 2015$ & 10 & 15000 & 20 \\
Plow & $5,400.00$ & $07 / 2013$ & 15 & 2500 & 5 \\
Harrow & $16,000.00$ & $05 / 2016$ & 15 & 2500 & 5 \\
Rotary hoe & $12,500.00$ & $04 / 2018$ & 12 & 2500 & 5 \\
Seeder & $54,000.00$ & $12 / 2015$ & 15 & 1200 & 20 \\
\hline
\end{tabular}


to keep machines working; actual costs may vary depending on differences in machine maintenance, management and quality. Repair and maintenance factors (RF1 and RF2) were those described in ASAE D497 (ASABE, 2011b).

Tractor lubrication costs were calculated considering the expenses with liquid lubricants, caused by periodic exchanges of oils, carried out every $500 \mathrm{~h}$, according to the manufacturer's recommendations, and the estimated consumption of grease, which was calculated based on the parameters provided by Balastreire (2004) and Pacheco (2000), who stated that grease consumption is equal to $0.05 \mathrm{~kg} \mathrm{~h}^{-1}$ for tractors and to $0.03 \mathrm{~kg}$ $\mathrm{h}^{-1}$ for implements. The cost of lubricating oils and grease was determined by multiplying the values of consumption by the respective prices of the products.

The costs of labor with tractor drivers included the monthly salary, benefits and social charges paid by the employers. The monthly salary used was that established by the Collective Labor Convention (Convenção Coletiva de Trabalho - CCT) $2017 / 2017$, which is valid for rural workers of the irrigated horticulture-fruticulture of the Sub-middle São Francisco Valley. To include labor charges and benefits, the percentage on the monthly salary adopted was the one used by the National Supply Company (CONAB) for workers hired through collective agreement (41.59\%) (CONAB, 2010).

The cost with fuel was calculated using the values of average hourly diesel consumption determined for each combination of treatments. Hourly consumption was determined by means of a flow meter, Flowmate Oval ${ }^{\circ}$ M-III, LSF41 model, installed in the tractor power system, whose previous calibration resulted in a flow of $3.60 \mathrm{~L} \mathrm{~h}^{-1} \mathrm{~Hz}^{-1}$. The average resale value of diesel S10 for 2017 (R\$3.215 $\mathrm{L}^{-1}$ ) was used to calculate the cost.

The cost of mechanized operations as a function of the cultivated area was determined by dividing the values of each component by the operational capacity of the respective sets. The operational capacity was estimated as the relationship between the area worked by each mechanized set (theoretical width $\mathrm{x}$ plot length) and the time spent performing the operation, which was recorded by the data collector used in the tractor instrumentation.

The costs for each combination of treatments were determined by adding the estimated values according to the sequence of operations and the corresponding conditions of water content.

Along the cycle, onion was irrigated using a localized drip irrigation system, composed of a motor pump, Branco brand, BD-704 SPL model, with engine power of $6.5 \mathrm{hp}$ and maximum flow rate of $78 \mathrm{~m}^{3} \mathrm{~h}^{-1}$, and its connections; DN 50 $\mathrm{mm}$ and DN $35 \mathrm{~mm}$ pipes; drippers with flow rates of $1.6 \mathrm{~L}$ $\mathrm{h}^{-1}$; initial connectors; end connectors; sealing rings; $50-\mathrm{mm}$ diameter valves; water filtration and suction system; system for fertigation; and reservoir.

The total annual cost of the irrigation system was determined based on the methodology presented by Marouelli \& Silva (2011), consisting of: fixed cost, which includes the depreciation of the system and the cost of opportunity of capital; and the variable cost, composed of the operating cost (expenses with fuel, labor and irrigation water) and the maintenance cost.
The useful life and factors for estimating the cost with maintenance of the irrigation system corresponded to the average value of the intervals proposed by Marouelli \& Silva (2011). The cost of interest was estimated using the average value of remuneration for savings deposits for 2017 (6.297\% p.a.) as an annual interest rate. The cost of water was calculated considering the fixed tariff $\mathrm{K} 1$, defined by the Ordinance No. 277 of the Ministry of National Integration for the period from January 1 to December 31, 2017.

Along the cultivation, basal and top-dressing fertilizations were applied according to agronomic recommendations for the crop. Basal fertilization was carried out broadcast, with incorporation of the fertilizer into the soil during the last seedbed raising operation. Top-dressing fertilization was performed via fertigation, applying the following formulations: $625.00 \mathrm{~kg} \mathrm{ha}^{-1}$ of granulated MAP (10-50-00); $50.00 \mathrm{~kg} \mathrm{ha}^{-1}$ of dripsol $^{\circledR}$ inicial (15-30-15); $66.67 \mathrm{~kg} \mathrm{ha}^{-1}$ of urea; 100.00 $\mathrm{kg} \mathrm{ha}^{-1}$ of purified MAP; $300.00 \mathrm{~kg} \mathrm{ha}^{-1}$ amiorgan $^{\circledast} \mathrm{LP} ; 208.33$ $\mathrm{kg} \mathrm{ha}^{-1}$ of calcium nitrate; $383.33 \mathrm{~kg} \mathrm{ha}^{-1}$ of potassium chloride; $383.33 \mathrm{~kg} \mathrm{ha}^{-1}$ of magnesium sulfate; and $4.17 \mathrm{~kg} \mathrm{ha}^{-1}$ of dripsol ${ }^{\circ}$ micro equilíbrio

When necessary, herbicides were applied for weed control, and insecticides and fungicides were applied to control pests and diseases, using a backpack sprayer.

The cost of fertilizers was determined by multiplying the amount necessary to fertilize one hectare by the value of acquisition of the product. The cost of pesticides was determined considering the applied doses, number of applications and purchase price of the products used. In both cases, the total cost corresponded to the sum of individual costs.

The cost with seeds was determined by multiplying the amount of seeds used in experimental plantation (12.92 $\left.\mathrm{kg} \mathrm{ha}^{-1}\right)$ by their price. Nunhems ${ }^{\circledast}$ seeds of the variety NUN 1205 were used. The cost of one seed package with net weight of $423.42 \mathrm{~g}$ was $\mathrm{R} \$ 550.00$.

The cost with bagging was estimated by multiplying the unit cost of nylon bags, with capacity for $20 \mathrm{~kg}$, by the number of bags required to pack the marketable bulbs (cross diameter equal to or greater than $35 \mathrm{~mm}$ ) produced in each subplot.

To determine the marketable yield, all plants present in a $2 \mathrm{~m}^{2}$ area, located in the central $10 \mathrm{~m}$ of each seedbed, were harvested. After a 4-day period of drying in the sun, the bulbs had their diameter measured. Those with diameter equal to or greater than $35 \mathrm{~mm}$ were weighed, and then the marketable yield was obtained.

The manual operations carried out along the cultivation were: application of agricultural pesticides, weeding, and harvesting of the bulbs produced. The cost of the operations of pesticide application was determined based on the amount of the monthly salary stipulated for the horticulture-fruticulture activity, plus the health risk bonus, established by the Collective Labor Convention 2017/2017, and a percentage of $41.59 \%$ on the monthly salary value related to labor charges and benefits (CONAB, 2010). The calculation considered only the period corresponding to the crop cycle (100 days) with a working day of $8 \mathrm{~h}$.

The cost of the manual weeding operation was calculated by multiplying the number of daily payments required to perform 
the operation by the amount paid in each daily payment ( $\mathrm{R} \$$ 45.00).

The cost of harvesting labor is negotiated between producers and workers, being defined according to the mass of bulbs harvested and cleaned (cutting leaves and roots). Thus, each bag of onion harvested $(20 \mathrm{~kg}$ ) represented a cost of $\mathrm{R} \$$ 3.00 , a value established according to the local prices in effect.

The cost of production per hectare of onion planted ( $R \$$ $\mathrm{ha}^{-1}$ ) was determined by summing the costs with mechanized operations, manual operations, irrigation system and inputs. The unit cost of production, in turn, was determined by dividing the cost of production by the marketable yield.

Gross revenue, net revenue and internal rate of return, indicators used to assess the economic efficiency of onion cultivation, were also determined according to the proposed treatments. The gross revenue of the crop was calculated based on the average price paid to the producer for the $20-\mathrm{kg}$ bag of onion ( $\mathrm{R} \$ 23.75 \mathrm{bag}^{-1}$ ), provided by CONAB (2018) for commercialization in the state of Bahia, Brazil.

Net revenue was obtained by subtracting the total cost of production from the estimated gross revenue. Thus, the treatments with the highest net revenues were considered the most favorable to onion crop planting.

The internal rate of return (IRR), which consists of a percentage measure of revenue on the initial capital invested in crop production, was calculated as proposed by Silva et al. (2012).

Cost data were subjected to analysis of variance. For the tillage system factor, the means were compared using the Tukey test at $\mathrm{p} \leq 0.05$. For the soil water content factor, regression analysis was applied, and the models were selected based on the behavior of the phenomenon, coefficient of determination and significance of the regression coefficients, using the t-test at $\mathrm{p} \leq 0.05$. The analyses were performed using the computer program R (R Core Team, 2017).

The economic efficiency of the treatments was evaluated through the economic indicators gross revenue, net revenue, internal rate of return and unit cost of production.

\section{Results AND Discussion}

The interaction between soil water contents and tillage systems did not significantly influence the cost of the mechanized operations required for onion crop planting, nor its marketable yield, which is presented in Table 2.

The total cost of mechanized operations and its components varied significantly as a function of the soil tillage systems (Table 3). The tillage system P1, composed of one plowing operation, two harrowings and two seedbed raising operations,
Table 2. Marketable yield onion $\left(\mathrm{t} \mathrm{ha}^{-1}\right)$ as a function of soil water content and tillage systems

\begin{tabular}{|ccccc|}
\hline Tillage & \multicolumn{4}{c|}{ Soil water content (\%) } \\
\cline { 2 - 5 } systems & $\mathbf{1 2}$ & $\mathbf{1 5}$ & $\mathbf{2 3}$ & $\mathbf{2 6}$ \\
P1 & 58.40 & 81.52 & 64.52 & 74.07 \\
P2 & 60.19 & 77.96 & 66.02 & 67.26 \\
P3 & 68.99 & 74.35 & 83.47 & 70.46 \\
CV (\%) & \multicolumn{4}{c}{21.38} \\
\hline
\end{tabular}

P1 - one plowing, two harrowings and two seedbed raising operations; P2 - two harrowings and one seedbed raising operation; P3 - one harrowings and one seedbed raising operation

was the one with the highest total cost. The systems P2 and P3 promoted, respectively, reductions of $23.53 \%\left(\mathrm{R} \$ 947.54 \mathrm{ha}^{-1}\right)$ and $24.71 \%\left(\mathrm{R} \$ 995.01 \mathrm{ha}^{-1}\right)$ of the total cost of mechanized operations in comparison to the P1 system.

These results are consistent with those obtained by Šarauskis et al. (2014), who conducted an economic evaluation of the mechanized operations necessary for corn cultivation and observed that the use of reduced soil tillage systems made it possible to reduce the cost with tillage because it required fewer machines and less working time and fuel, contributing to the reduction of the total cost of production.

As the higher cost of operations for the P1 tillage system did not correspond to a significant gain in marketable yield, and the reduction in the number of operations did not result in significant losses in the production of marketable bulbs, it is possible to affirm that, under the conditions in which the experiment was carried out, the tillage system P3 is the most recommended for onion cultivation, since it numerically led to lower total cost (Table 3) and higher average marketable yield (Table 2).

Depreciation was the most pronounced fixed cost component (D + I + S/INS), corresponding to 53.99, 52.74 and $52.61 \%$ of this cost (Table 3 ) in the tillage treatments P1, P2 and P3, respectively. Among the variable costs, fuel consumption generated the highest values regardless of the tillage system used. The use of P2 and P3 systems reduced the cost with fuel by 25.31 and $25.58 \%$, respectively, when compared to P 1 . Lower costs with repairs and maintenance, lubricants and labor per cultivated hectare were obtained when the P3 tillage system was used.

The total cost of the irrigation system, which comprised depreciation, cost of opportunity, maintenance, irrigator's labor, fuel and irrigation water, was estimated at $\mathrm{R} \$ 24,818.77 \mathrm{ha}^{-1}$ year ${ }^{-1}$, being the same for all treatment combinations, since there was no variation between them regarding irrigation management. Rabiou et al. (2018) pointed out that mastering the irrigation techniques is necessary to achieve optimal performance and effectively reduce onion production costs, since the use of irrigation generates high expenses, especially with regard to the activation of motor pump sets.

Table 3. Cost of the mechanized operations used in onion crop planting as a function of the soil tillage systems

\begin{tabular}{|c|c|c|c|c|c|c|c|c|}
\hline \multirow{2}{*}{$\begin{array}{l}\text { Tillage } \\
\text { system }\end{array}$} & D & I & S/INS & $\mathrm{R} / \mathrm{M}$ & $F$ & Lu & La & TC \\
\hline & \multicolumn{8}{|c|}{$\mathrm{R} \$ \mathrm{ha}^{-1}$} \\
\hline P1 & $785.90 \mathrm{a}$ & $546.53 \mathrm{a}$ & $123.25 \mathrm{a}$ & $705.16 \mathrm{a}$ & $1.424 .32 \mathrm{a}$ & $171.62 \mathrm{a}$ & $269.66 \mathrm{a}$ & $4.026 .44 \mathrm{a}$ \\
\hline P2 & $640.65 b$ & $468.82 \mathrm{~b}$ & $105.16 \mathrm{~b}$ & $511.26 \mathrm{~b}$ & $1.063 .87 b$ & $112.45 b$ & $176.69 \mathrm{~b}$ & $3.078 .90 \mathrm{~b}$ \\
\hline P3 & $629.05 b$ & $462.87 \mathrm{~b}$ & $103.71 b$ & $499.40 \mathrm{C}$ & $1.059 .96 \mathrm{~b}$ & $107.51 \mathrm{c}$ & $168.92 \mathrm{c}$ & $3.031 .43 b$ \\
\hline CV $(\%)$ & 11.06 & 8.56 & 8.83 & 16.95 & 16.71 & 22.75 & 22.75 & 14.21 \\
\hline
\end{tabular}

Means followed by the same letter in the column do not differ by Tukey test at $\mathrm{p} \leq 0.05$; D - Depreciation; I - Interest rate; S/INS - Shelter and insurance; R/M - Repair and maintenance; F - Fuel; Lu - Lubricants; La - Labor; TC - Total cost; P1 - one plowing, two harrowings and two seedbed raising operations; P2 - two harrowings and one seedbed raising operation; P3 - one harrowing and one seedbed raising operation 
The costs with fertilizers, pesticides and seeds were $\mathrm{R} \$$ 3,416.97, R\$ 856.76, and R $\$ 16,784.23$ ha $^{-1}$, respectively. The same management was applied to all experimental units, so there was no variation in these costs.

The cost with bagging, the total cost of inputs, the cost of harvesting and the total cost with manual operations were not significantly influenced by the factors studied. Their average values were $\mathrm{R} \$ 3,353.64, \mathrm{R} \$ 24,411.60, \mathrm{R} \$ 10,590.44$ and $\mathrm{R} \$$ $29,331.72 \mathrm{ha}^{-1}$.

The seeds accounted for most of the cost with inputs, corresponding on average to $69.0 \%$ of it. On the other hand, the costs with fertilizers, pesticides and bagging corresponded to 14,4 and $14 \%$, respectively. These results are consistent with those obtained by Araújo \& Correia (2010), who analyzed the production costs and profitability of onion exploitation in the Sub-middle São Francisco Valley and observed that, among the inputs, bagging and seeds were the most expensive items.

Jain \& Gupta (2018), in turn, when analyzing onion production costs for small, medium and large farms in India, observed that for farmers with areas of up to two hectares (small), like those of the Sub-middle São Francisco Valley, the input that most burdened the producer was the seed, corroborating the results presented earlier.

The cost of weeding was $\mathrm{R} \$ 13,500.00 \mathrm{ha}^{-1}$, which corresponded to $46.03 \%$ of the total cost with manual operations. This cost can be reduced if the effectiveness of weed control with herbicide application is increased. The manual application of pesticides, in turn, generated an expense of $\mathrm{R} \$$ $5,241.28 \mathrm{ha}^{-1}$.

As the weeding operation, harvesting also had a high cost (on average $36.11 \%$ of the total cost of manual operations). This occurred because, unlike the application of pesticides, these operations are specific and require a large amount of labor and working time, as also found by Hawary et al. (2017).

The cost with labor for harvest can be reduced with the mechanization of this operation. Nisha \& Shridar (2018) observed that the use of a small onion harvester whose power source was a motor-cultivator resulted in reductions of $59.2 \%$ in the cost and $93.75 \%$ in the time spent with manual harvesting of onions.

The costs of production per hectare and ton of onion produced did not vary significantly as a function of the tillage systems and soil water contents. Their average values are presented in Tables 4 and 5.

The average cost of cultivation of one hectare of onions, under these experimental conditions, was R 81,941.02. Hunguer (2013) presented in his study a cost of production lower than this ( $\mathrm{R} \$ 10,698.0)$, a difference that may be associated with the inclusion of distinct components in the

Table 4. Cost of onion production per hectare $\left(\mathrm{R} \$ \mathrm{ha}^{-1}\right)$ as a function of soil water content and tillage system

\begin{tabular}{|ccccc|}
\hline Tillage & \multicolumn{4}{c|}{ Soil water content (\%) } \\
\cline { 2 - 5 } system & $\mathbf{1 2}$ & $\mathbf{1 5}$ & $\mathbf{2 3}$ & $\mathbf{2 6}$ \\
P1 & $80,073.42$ & $84,738.64$ & $81,416.49$ & $83,356.27$ \\
P2 & $79,535.85$ & $83,145.07$ & $80,718.96$ & $80,996.67$ \\
P3 & $81,288.28$ & $82,389.03$ & $84,052.74$ & $81,580.75$ \\
CV (\%) & \multicolumn{4}{c}{3.65} \\
\hline
\end{tabular}

P1 - one plowing, two harrowings and two seedbed raising operations; P2 - two harrowings and one seedbed raising operation; P3 - one harrowings and one seedbed raising operation
Table 5. Cost of production per ton of onion $\left(R \$ t^{-1}\right)$ as a function of soil water content and tillage system

\begin{tabular}{ccccc}
\hline Tillage & \multicolumn{4}{c}{ Soil water content (\%) } \\
\cline { 2 - 5 } system & $\mathbf{1 2}$ & $\mathbf{1 5}$ & $\mathbf{2 3}$ & $\mathbf{2 6}$ \\
P1 & $1,417.83$ & $1,054.60$ & $1,295.00$ & $1,132.14$ \\
P2 & $1,354.59$ & $1,094.35$ & $1,268.16$ & $1,297.32$ \\
P3 & $1,250.13$ & $1,143.94$ & $1,014.73$ & $1,206.22$ \\
CV (\%) & \multicolumn{4}{c}{20.51} \\
\hline
\end{tabular}

P1 - one plowing, two harrowings and two seedbed raising operations; P2 - two harrowings and one seedbed raising operation; P3 - one harrowings and one seedbed raising operation

calculation, as well as the cost associated with the possession of agricultural machinery and equipment, which includes depreciation, interest on invested capital and the cost with maintenance and repairs.

The lowest cost per ton of onion produced $\left(\mathrm{R} \$ 1,014.73 \mathrm{t}^{-1}\right)$ was obtained for the combination between soil water content of $23 \%$ and the tillage system P3, which also led to highest gross revenue $\left(\mathrm{R} \$ 99,126.56 \mathrm{ha}^{-1}\right)$, highest net revenue $(\mathrm{R} \$ 15,073.82$ $\mathrm{ha}^{-1}$ ) and highest rate of return (17.74\%) (Table 6).

These results demonstrate that good performance in onion cultivation is not necessarily linked to excessive breaking of soil clods, so it is feasible to reduce the number of tillage operations, provided that attention is given to soil consistency, defined by the water content present.

The variation observed in gross revenue values (Table 6) is associated with the variation obtained between treatments for marketable yield of bulbs. Although these differences were not large enough to be considered statistically significant, they were all higher than one ton of bulbs per hectare, which for the producer may mean the difference between profit and loss with onion cultivation.

Therefore, soil tillage, at a water content of $23 \%$, with only one harrowing and one seedbed raising operation resulted in the highest economic efficiency promoted by the highest yield obtained and the lowest cost of production.

Table 6. Indicators of economic efficiency for onion cultivation as a function of the studied treatments ${ }^{1}$

\begin{tabular}{|c|c|c|c|c|}
\hline \multirow{2}{*}{$\begin{array}{c}\text { Soil water } \\
\text { content } \\
(\%)\end{array}$} & \multirow{2}{*}{$\begin{array}{c}\text { Tillage } \\
\text { systems }\end{array}$} & $\begin{array}{l}\text { Gross } \\
\text { revenue }\end{array}$ & $\begin{array}{c}\text { Net } \\
\text { revenue }\end{array}$ & \multirow{2}{*}{$\begin{array}{l}\text { Internal rate } \\
\text { of return (\%) }\end{array}$} \\
\hline & & \multicolumn{2}{|c|}{$\left(\right.$ R ha $\left.^{-1}\right)$} & \\
\hline \multirow{3}{*}{12} & P1 & $69,350.00$ & $-10,723.42$ & -13.77 \\
\hline & P2 & $71,472.66$ & $-8,063.20$ & -10.45 \\
\hline & P3 & $81,930.08$ & 641.80 & -0.18 \\
\hline \multirow{3}{*}{15} & P1 & $96,810.94$ & $12,072.30$ & 13.93 \\
\hline & P2 & $92,580.47$ & $9,435.39$ & 10.86 \\
\hline & P3 & $88,290.62$ & $5,901.59$ & 6.54 \\
\hline \multirow{3}{*}{23} & P1 & $76,613.54$ & $-4,802.94$ & -6.31 \\
\hline & P2 & $78,404.69$ & $-2,314.27$ & -3.34 \\
\hline & P3 & $99,126.56$ & $15,073.82$ & 17.74 \\
\hline \multirow{3}{*}{26} & P1 & $87,964.06$ & $4,607.79$ & 5.43 \\
\hline & P2 & $79,874.22$ & $-1,122.45$ & -2.33 \\
\hline & P3 & $83,674.22$ & $2,093.46$ & 1.98 \\
\hline
\end{tabular}

${ }^{1}$ Indicators obtained based on the average sale price of onion in October 2017 (R $\left.\$ 23.75\right)$ P1 - one plowing, two harrowings and two seedbed raising operations; P2 - two harrowings and one seedbed raising operation; P3 - one harrowings and one seedbed raising operation

\section{Conclusions}

1. The use of the tillage system composed of one harrowing and one seedbed raising operation, followed by sowing, together with a soil water content of $23 \%$, minimizes the unit cost of onion production ( $\left.\mathrm{R} \$ 1,014.73 \mathrm{t}^{-1}\right)$ and maximizes gross 
revenue ( $\left.\mathrm{R} \$ 99,126.56 \mathrm{ha}^{-1}\right)$, net revenue $\left(\mathrm{R} \$ 15,073.82 \mathrm{ha}^{-1}\right)$ and the internal rate of return in the activity (17.74\%).

2. The tillage system composed of one harrowing and one seedbed raising operation is the most recommended from the economic point of view for onion crop planting.

\section{Literature Cited}

Araújo, J. L. P.; Correia, R. C. Análise dos custos de produção e da rentabilidade do sistema típico de produção da cebola na região do Submédio São Francisco. In: Congresso da Sociedade Brasileira de Sistemas de Produção, 8, 2010, São Luís. Anais... São Luís: UEMA/Embrapa Cocais, 2010.

ASABE - American Society of Agricultural and Biological Engineers. Agricultural machinery management data: ASAE EP496.3. St. Joseph: ASABE, 2011a. 7p.

ASABE - American Society of Agricultural and Biological Engineers. Agricultural machinery management data: ASAE D497.7. St. Joseph: ASABE, 2011b. 9p.

Balastreire, L. A. Máquinas agrícolas. Piracicaba, 2004. 302p.

Barakade, A. J.; Lokhande, T. N.; Todkari, G. U. Economics of onion cultivation and it's marketing pattern in satara district of Maharashtra. International Journal of Agriculture Sciences, v.3, p.110-117, 2011. https://doi.org/10.9735/0975-3710.3.3.110-117

CONAB - Companhia Nacional de Abastecimento. Custos de produção agrícola: A metodologia da CONAB. Brasília: CONAB, 2010.60p.

CONAB - Companhia Nacional de Abastecimento. Programa brasileiro de modernização do mercado de hortigranjeiro: Média mensal dos preços. 2018. Available on: <http://www3.ceasa.gov. br/prohortweb/> Accessed on: Jan. 2019.

Corso, C. A.; Ruppenthal, I. L.; Kalkmann, M. L. Análise econômica em uma pequena propriedade rural para tomada de decisão. Brazilian Journal of Development, v.4, p.801-813, 2018.

Costa, N. R.; Andreotti, M.; Bergamaschine, A. F.; Lopes, K. S.; Silva Lima, A. E. Custo da produção de silagens em sistemas de integração lavoura-pecuária sob plantio direto. Revista Ceres, v.62, p.9-19, 2015. https://doi.org/10.1590/0034-737X201562010002

Feitosa, E. O.; Araújo, F. B.; Lopes, F. B.; Andrade, E. M.; Bezerra, F. M. L. Análise de custos e rentabilidade na produção de mamão irrigado no semiárido. Revista Brasileira de Agricultura Irrigada, v.12, p.2293-2304, 2018. https://doi.org/10.7127/rbai.v12n100686

Hawary, M. Y.; Abdalla, A. S.; Elfadil, A. D.; Elkashif, M. E. Evaluation of the traditional method of onion transplanting under Gezira conditions, Sudan. Sinnar University Journal, v.3, p.143-154, 2017.

Heidarisoltanabadia M.; Tahani, B. An investigation into energy consumption for onion cropping. ISESCO Journal of Science and Technology, v.12, p.50-56, 2016.

Hunguer, H. Produtividade e análise econômica da cultura da cebola sob diferentes densidades de plantio e níveis de adubação. 2013. 52p. Guarapuava: UNICENTRO. Dissertação Mestrado

Jain, S.; Gupta, J. K. Benefit: Cost analysis of onion producer in Sagar district of Madhya Pradesh, India. International Journal of Current Microbiology and Applied Sciences, v.7, p.894-900, 2018. https://doi.org/10.20546/ijcmas.2018.701.109
Loss, A.; Basso, A.; Oliveira, B. S.; Koucher, L. P.; Oliveira, R. A.; Kurtz, C.; Lovato, P. E.; Curmi, P.; Brunetto, G.; Comin, J. J. Carbono orgânico total e agregação do solo em sistema de plantio direto agroecológico e convencional de cebola. Revista Brasileira de Ciência do Solo, v.39, p.1212-1224, 2015. https:// doi.org/10.1590/01000683rbcs20140718

Loss, A.; Santos Junior, E.; Schmitz, D.; Veiga, M.; Kurtz, C.; Comin, J. J. Atributos físicos do solo em cultivo de cebola sob sistemas de plantio direto e preparo convencional. Revista Colombiana de Ciencias Hortícolas, v.11, p.105-113, 2017. https://doi. org/10.17584/rcch.2017v11i1.6144

Marouelli, W. A.; Silva, W. L. C. Seleção de sistemas de irrigação para hortaliças. Brasília: Embrapa Hortaliças, 2011. 23p.

Menezes Júnior, F. O. G.; Kurtz, C. Produtividade da cebola fertirrigada sob diferentes doses de nitrogênio e densidades populacionais. Horticultura Brasileira v.34, p.571-579, 2016. https://doi.org/10.1590/s0102-053620160418

Moraes, C. C.; Araújo, H. S.; Factor, T. L.; Purquerio, L. F. V. Fenologia e acumulação de nutrientes por cebola de dia curto em semeadura direta. Revista de Ciências Agrárias, v.39, p.281-290, 2016. https:// doi.org/10.19084/RCA15109

Nisha, N., Shridar, B. Development of power tiller operated harvester for small onion (Allium cepa var. Aggregatum). International Journal of Agricultural, v.8, p.73-78, 2018. https:// doi.org/10.24247/ijasrfeb201811

Oliveira, M. D. M.; Nachiluk, K. Custo de produção de cana-de-açúcar nos diferentes sistemas de produção nas regiões do Estado de São Paulo. Informações Econômicas, v.41, p.5-33, 2011.

Özgöz, E.; Altuntaş, E.; Asiltürk, M. Effects of soil tillage on energy use in potato farming in Central Anatolia of Turkey. Energy, v.141, p.1517-1523, 2017. https://doi.org/10.1016/j.energy.2017.11.037

Pacheco, E. P. Seleção e custo operacional de máquinas agrícolas. Rio Branco: Embrapa Acre, 2000. 21p.

Painter, K. Costs of owning and operating farm machinery in the Pacific Northwest: 2011. Pacific Northwest Extension Publication, v.346, p.1-106, 2011.

R Core Team. R: A language and environment for statistical computing. Vienna: R Foundation for Statistical Computing, 2017. Available at: <URL:http://www.rproject.org/>. Accessed on: Nov. 2018.

Rabiou, M. M.; Moussa, I.; Mella, M. T.; Sadou, H. Panorama of onion production in Tillabéri, a region of the far west of Niger. European Scientific Journal, v.14, p.175-196, 2018. https://doi.org/10.19044/ esj.2018.v14n15p175

Šarauskis, E.; Buragiené, S.; Masilionyté, L.; Romaneckas, K.; Avižienyté, D.; Sakalauskas, A. Energy balance, cost and $\mathrm{CO}_{2}$ analysis of tillage technologies in maize cultivation. Energy, v.69, p.227-235, 2014. https://doi.org/10.1016/j.energy.2014.02.090

Silva, A.; Yuri, J.; Resende, G. M. Dinâmica da produção brasileira de cebola entre 1990 e 2012. Horticultura Brasileira, v.31, p.270275, 2014.

Silva, M. L.; Jacovine, L. A. G.; Valverde, S. R. Economia florestal. 2.ed. Viçosa: Editora UFV, 2012, 178p. 